\title{
Effect of Learning "Outdoor Study" Ability to Communicate in Writing and Social-Geography Student Learning Outcomes at "Mataraman" East Java-The Republic of Indonesia*
}

\author{
Ach. Fatchan \\ Faculty of Social Sciences - State University of Malang - Republic of Indonesia \\ Email: Ach.Fatchan.fis@um.ac.id \\ Hadi Soekamto \\ Faculty of Social Sciences - State University of Malang - Republic of Indonesia \\ Email: Hadi.Soekamto.fis@um.ac.id \\ Sumarmi \\ Faculty of Social Sciences - State University of Malang - Republic of Indonesia \\ Email: Sumarmi.fis@um.ac.id

\section{Sugeng Utaya} \\ Faculty of Social Sciences - State University of Malang - Republic of Indonesia \\ Email: Sugeng.Utaya.fis@um.ac.id
}

Doi:10.5901/mjss.2016.v7n3p429

\begin{abstract}
This study aims to explain the influence of the learning model "outdoor study" of the ability to communicate through writing or "paper" and the result of learning social-geography students. Learning model "outdoor study" done by the students conduct field observations and interviews. The ability to communicate through writing is measured based on the task of making "paper". Learning outcomes are measured through the pre-test and post-test. This study was designed using quasi experiment with non-equivalent patterns of pre-post test control group desaign. The research location in the Midle Junior School in the area "Mataraman" East Java Province. Area "Mataraman" is Blitar, Tulungagung, and Bojonegoro. Analysis of data using test scores and gain one-way ANOVA with a confidence level of 0.05 . The results showed that the learning model "outdoor study" effect on the ability to communicate through writing or paper with a score of $F$ calculate equal to 6.410 . Furthermore, also affects the learning outcomes geography scores $F$ calculate equal to 7.114 . In which both scores indicate greater than the value of $F$ table 4.00. Thus, it can be concluded that the study "outdoor study" through observation and field interviews, not only can improve learning outcomes, but also can improve students' skills in writing papers in the field of geography. Such learning is necessary implemented in Junior Midle School since been shown to improve the ability to write "paper" and student learning outcomes.
\end{abstract}

Keywords: outdoor study, field observation, papper, and the result of learning social-geography

\section{Background}

To acquire learning that can be run in a conducive, it must create an atmosphere that can achieve the goal of effective and efficient learning. One form is an attempt student learning. That is, in learning not only the interaction between students and teachers, but also the interaction with learning resources that exist in the environment around the students. It was necessary because, the problems of education in Indonesia is the urgent implementation of the system and poor learning. In the implementation of learning in school, many found the application of learning methods are imprecise and lacking interest of students. It causes the student motivation and student learning outcomes are low (Ministry of National Education and Culture, 2013). During this study conducted by the teachers tend to lead to the ability to memorize facts. As a result, students only strong level of memorization, but low in understanding the nature of the substance of the material being studied. To that end, the need for a change of learning that emphasizes the mastery of the material becomes emphasis on process skills. The goal for the students' ability to find and understand the concept of the subject 
matter better. To achieve such objectives, one of which allegedly learning model is the right thing to do learning model of "outdoor study".

As we know that the learning model "outdoor study" as one of contextual learning model which began to be applied by teachers of Geography in Indonesia (Geography Lecturer Team, 1995). Learning it is more directed to the development of life skills of students (Setjo, 2003), and contextual teaching and learning (Nurhadi. 2002). He was one of learning to use a scientific approach that is consistent with the chronological active and creative thinking of students. The underlying assumption is that students learn to construct concepts through his own life experiences and not memorizing concepts. He is one of the pattern transformation education for the students themselves with the environment (Fatchan, et al, 2004). He is also a constantly learning using learning resources context of everyday life of students. The goal is that students can apply the material relating to the geography lesson find and can simultaneously solve the problems encountered in everyday life. Patterns such learning requires students active and creative thinking (Crawford, 2001). In the implementation of learners can directly interact and learn the condition of natural resources and or human resources that are around the school.

Contextual learning as one of the important lessons to be applied in Indonesia (College of Education, 2001). So also in learning the material to the object of social-geography, he is likely much relevant in the context of everyday life, including: (1) The natural conditions such as rivers, lakes, seas, mountains, deltas, paddy fields, dry land, and plantations; (2) The condition of human resources such as social, economic, demographic, population employment, housing, and cultural communities that exist around schools (Fatchan, Purwito, Marhadi, and Sukamto 2005). Simply put, the geography is always asked about "where" symptoms occur. Thus, the application of learning "outdoor study" makes the students are able to build or define their own concepts on a based on observations or interviews directly in the field.

Field activities related to the object of study of social-geography in the form of the phenomenon of the geosphere and the various problems that occur in the surrounding environment of human life. Patterns of learning should not just transfer knowledge to students, but also gives the freedom to the students to feel, observe, analyze, find and conclude. Therefore, the teacher's role is as a mentor, facilitator and motivator who helps the student in the learning process. Learning such as self-direct learning patterns (Kunkel, 1975). Learning where students can freely construct what is seen, observed, written and presented based on his experience, so as to develop students' life skills.

In applying the learning model "outdoor study", takes a sequence of phases of activity. Stages were as follows: observe, classify, communicate, measures, projects, concluded and write a report on the results of study (Rostana, 2002; Fatchan, Purwito, Marhadi and Sukamto 2005; Fatchan, Amirudin, and Utaya, 2012). Each learning results obtained can be used to see if the student has made the learning process. Basically any learning process "outdoor study" is a pattern of self-direct learning application. So that in passing the results of the acquisition of learning can not be seen by others, but can only be felt by the students themselves. Thus, the measurement and assessment of student learning outcomes can be measured by demonstrating the extent to which the material is learned can be understood and mastered by students. One form is communicated via paper.

Implementation of learning "outdoor study" on a matter of social-geography can evoke motivation and student activity. One form of learning gained through experience in the field. Where allows teachers to foster student motivation. It is known that motivation is an important element in the learning process is seen as a mental boost to propel and steer the behavior of student learning. Staton (1978) referred to it as a way of teaching to expect the best results. In the motivation contained the desires, hopes, needs, goals, objectives and incentives. Psychiatric conditions that enable this kind, mobilizing, channeling and directing the students' attitudes and behavior.

The existence of a mental boost in self-esteem, will automatically direct impact on student behavior. The behavior demonstrated when students observe, pay attention to, discuss, solve problems and make comparisons between the textbook and the reality on the ground, until the time of making a final conclusion (Dimyati and Mudjiono, 1994). In other words, that the mental boost in the form of motivation and student activity will be a direct impact on student learning outcomes. Because the learning outcomes is the culmination of the learning process. The learning result is essentially the student's behavior changes as a result of the learning process. The changes may include knowledge, understanding, skills, and attitudes.

Roadmap research was done by the previous study showed the following: Research Robenson (1977) and the Cross (1983) is based on research results in lowa and California noted that the appreciation of the learning outcomes, creating a supportive environment, the orientation of socio-cultural factors and geography and the existence of conditions of residence can bring a positive attitude to the study. To that end, model of learning that is done must be related to life skills learners (The Ministry of National Education and Culture, 2000) The provision of innovative information is necessary for an active and creative learning. Therefore, the information should be designed to support and assure for the study in order to learn more active. Accurate information can provide a potential opportunity and the right choice for the desire to 
learn. The information spread and can adequately support the motivation to learn. To that end, the environmental conditions of the context around the lives of students as learning media is very supportive for the success of learning (Amirudin, Fatchan, and Budijanto, 2006).

The research results Fatchan, et al (2004) showed that the application of learning "Social Studies-Geography" based problems that exist in the surrounding environment students can improve concentration, activity, and student motivation. Furthermore, the involvement of parents in school education management makes the process more conducive to learning in school. Students become more understanding of the meaning of life and life and life skill increased. The findings further indicate that learners who follow project based learning to give effect to the activity, creativity, courage students in expression. That's because it is supported by the props are presented by the teacher is quite interesting. Teaching aids in the form of a model of one of the objects of material suitable geography (Fatchan; Purwito; Marhadi; and Sukamto. 2005). However, common weaknesses that students have difficulty elaborating material object geography. The reason is because using mock objects that exist in the laboratory, not a real object. This is a weakness that will be corrected in this research, namely learning using real objects or students doing "outdoor study".

Contextual learning through field observation in areas frequently hit by natural disasters can increase students' learning activities Junior Midle School (Fatchan and Purwanto, 2007). Furthermore, in "action research" they do show that the student's behavior is more concerned about the environment and the attitude of the quick response in case of natural disasters. Responsive attitude was evidenced by the constructive response of the alternative solutions to problems and how to cope with disasters. If a disaster occurs that students can provide concrete steps how to avoid or overcome them. It is proved that the teaching of geography in schools can not be separated from the environment as an object of study. In other words, the environment around the student turns out to be a good source of learning geography. Thus, the learning model "outdoor study" on a matter of geography should be introduced and published in all levels of schools in Indonesia. Therefore, this study seeks to test the reliability of the learning model "outdoor study" on learning outcomes and writing paper material midle of geography at the Junior Midle School in the area "Mataraman" East Java Province.

\section{Methods}

The design of this study using quasi experimenal with pretest-posttest control group design. Learning results are measured through the pre-test and post-test. The ability to communicate is measured from a paper written by students in groups, each group consisting of 3 persons (only measured at the end of the collecting paper or post-test). The assessment criteria used paper Scientific Writing Guidelines of State University of Malang (Team PPKI, 2010). Aspects assessed include the writing and presentation: the title, the background of the problem, formulation of the problem, a literature review, the exposure results, discussion, conclusions, and references referred. Each of these aspects has a different weight value. Range assessment using lickert 1-5 scale, a minimum total score of 0 and a maximum score of 300. In the schematic design of this study as follows.

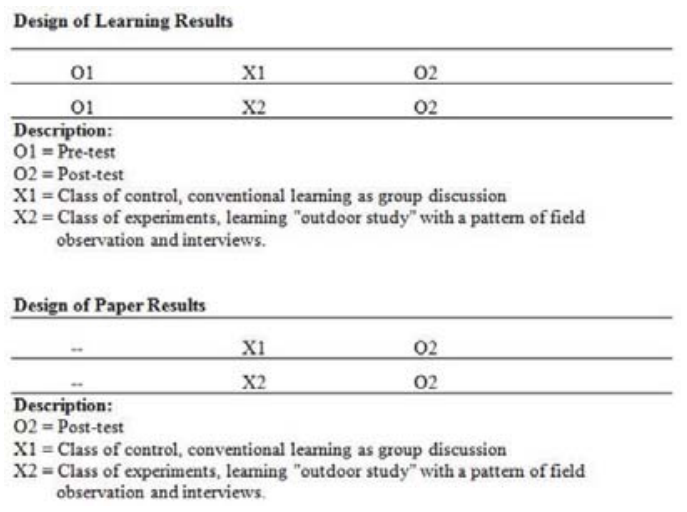

The research location is Midle School Junior class of 8 in the area of "Mataraman" East Java. Area "Mataraman" is Blitar, Tulungagung, and Bojonegoro. The subjects were students of class 8. Class of experimental and control class were selected based on the category of the average score of the last half of the homogeneous. That is, a class that has an 
average score of the "semester" with the smallest difference. Where class of 8-A (experimental class average score $=$ 62.74 ) and class of $8-C$ (control class average score $=62.81$ ). Analysis of data using test scores and gain one-way ANOVA with a level of data 0.05. Analisis aided by calculation using the services of a computer with SPSS by Windows.

\section{Research Results}

\subsection{Writing Ability Papper Material of Social-Geography}

As shown in this research goals that are tested in this research is the ability of students to write a paper and the results studied geography in school material. The ability to write paper is measured using indicators that exist in "Team PPKI" issued by the State University of Malang. Assessment is done on all papper written by students. Research results as shown in Table 1 below.

Table 1: The percentage of students in the Youth Ability Midle School in Writing Paper

\begin{tabular}{clccc}
\hline No. & Lokasi & Experiment Class & Control Class & Gain Score (\%) \\
\hline 1. & Blitar & 246.70 & 201.50 & 45.20 \\
2. & Tulungagung & 237.85 & 192.30 & 45.55 \\
3. & Bojonegoro & 243.64 & 199.30 & 44.34 \\
\hline & Rate & 242.73 & 197.70 & 45.03 \\
\hline
\end{tabular}

Based on the analysis of data as in Table 1 above, that in all the papers written by the students showed that the average value of the experimental class amounted to $242.73 \%$, relatively high in the criteria. While in the control class shows at $197.70 \%$, classified in the low criteria. Thus, the large increase in the average value (gain score) between the experimental class and control class by $45.03 \%$. This means that the ability to write paper on experimental class students on average higher than the control class. The score gain value supported by the test results obtained ANOVA analysis results calculated $F(6,410)>F$ table $(4: 00)$. That is, there is a positive influence between the application of learning "outdoor study" based on observations and interviews in the field of the student's ability to write paper on a matter of geography. Particularly in the matter "population problems and countermeasures" at the Yunior Midle School 8th grade.

\subsection{Results of Social-Geography Learning}

Questions used to measure learning outcomes social-geography consists of 10 questions in the form of an objective test (multiple choice) and 5 about the form of an essay test. Each problem is to test the validity of the content, level of difficulty, reliability, and power difference. To that end, the tests are limited and further revision. In the end, the result that has met the validity, which is as follows: (1) In the multiple choice questions about the content validity and reliability is high, ie 0.784 . Test item indicates the difficulty level of $60 \%$ which is quite good. Different power test results showed excellent item which amounted to 40\%; (2) In the matter of an essay test showed content validity and reliability is high ie about 0.660 . Test item indicates the difficulty level of $50 \%$ is quite good. The test results show the different power good items, which amounted to $30 \%$. Thus, based on the analysis of various questions that are used to pre-test and post-test in this research has been qualified as a test item in an experiment. Furthermore, based on the analysis of these results gain score as shown in Table 2 below.

Table 2: Percentage of Students Studying Social-Geography at Junior Midle School

\begin{tabular}{clcc}
\hline No. & Pre-Post Test & Experiment Class & Control Class \\
\hline 1. & Post-Test & 86.60 & 75.40 \\
2. & Pre-Test & 64.27 & 61.91 \\
\hline & Gain Score & 22.33 & 13.49 \\
\hline
\end{tabular}

Based on Table 2, shows that the results of the study the average pre-test score of 64.27 to 61.91 to the experimental class and control class. While the value of post-test of 86.60 shows the experimental class and the control class 75.40 . Thus, the value of the gain scores of post-test experimental class at 22.33 and grade control at 13.49. Experimental class scores gain value is greater than the control class. So it can be said that the results of learning social-geography 
experimental class is higher than the control class learning outcomes. In other words, the learning outcomes in learning social-geography "outdoor study" based on field observation and interviews superior compared to conventional learning.

Based on the test results of one-way ANOVA showed that the calculated value of 0.003 is smaller than the value of table 0.05 . Thus, we can conclude that the results of the use of learning social-geography lesson "outdoor study" is better than the conventional study conducted in the Midle Junior School in the area "Mataraman". It is strengthened by the acquisition of $\mathrm{F}$ count (7.114) greater with $\mathrm{F}$ table (4.00). In other words, there is a significant influence between the learning outcomes of learning social-geography with "outdoor study" based on field observation and interviews.

\section{Discussion}

\subsection{Writing Paper Material of Social-Geography}

The findings of this research show that the average value of the experimental class grade is high and control is low. That is, the ability to write paper on experimental class students on average better than the control class. This was reinforced by a score calculated $\mathrm{F}$ value is greater than the $\mathrm{F}$ table. In other words, there is a positive influence between the application of learning "outdoor study" is based on field observation and interviews with the students' ability to write papers in a matter of social-geography.

The students can write the contents of paper well due to the experience of field observations and interviews conducted. Furthermore, they get what they pour in writing papper. These findings are supported and supplemented the findings of previous research as follows: (1) the findings of Tim Lecturer in Geography (1995) who noted that the students' learning geography make observations of the object actually is superior in the acquisition of learning outcomes, the courage to write, argue, debate, and provide a solution to the problem. The research findings prove that the courage to write and argue as outlined in the paper not only in college, but also on the Junior Midle School students; (2) The results of this study are also in line with what result research by Crawford (2001) that students can apply the lesson material pertaining to find, solve problems, active and creative thinking as they directly interact with the surrounding environment. In other words, how students learn with style and his own way (Bruce, 1996).

Facts on the ground, at the time of the experiment, showed that students who are in the experimental group are more concerned with the environment. It was indicated at the time they respond to a question during a discussion in class. They tend to be explained based on the facts and issues in the field that they have encountered. While the control class who never do field observation have limitations in defining, developing knowledge, various facts the real problems that exist in the field.

At the time of implementation of learning "outdoor study" found several student activities that are positive, among others: (1) creative students appeared when preparing paper; (2) foster cooperation, responsibility, and respect other students' opinions are different when conducting group discussions; (3) compact in completing writing paper; (4) concern and increasing students' reasoning in solving problems encountered in the field; (5) determine the benefits and application of social-geography subjects in everyday life. This is because such learning related to everyday life skills students (The Ministry of National Education and Culture, 2002). However, encountered some obstacles are as follows: (1) To conduct "outdoor study" takes a special outside school hours, so teachers should make the lattice observations and interview; (2) The manufacture of paper are still rare and have not even been done by students require special instructions and guidance; (3) That all students actively learn and work it would require a clear division of labor by the teacher at the time "outdoor study" and writing paper.

Various research findings excellence "outdoor study" The above shows the complete findings of previous research. The findings noted that the learning material through the Social Sciences "outdoor study" superior in learning outcomes compared to learning "indoor study". Learning outside the classroom using the "outdoor study" can develop things that are positive, such as active power and creative students, so that students are more responsive in solving the problem based on the fact that they have encountered in the field of the "indoor study" that exist only in the classroom (Amirudin, Fatchan, and Sumarmi, 2009). Previous research was conducted in the context of the subject matter of Social Sciences in Junior Midle School while the research is done in the context of social-geography matter in Junior Midle School.

\subsection{Results of Social-Geography Learning}

Social-Geography learning outcomes showed score gains between pre-test and post-test experimental class larger than the class of the control. Furthermore, based on one-way ANOVA test results indicate that the use of learning outcomes social-geography lesson "outdoor study" is better than the conventional study conducted in the Junior Midle School in the 
area "Mataraman". That's because in the implementation on the ground that learning "outdoor study" based field observation and interviews directly raises students' activity. Furthermore, it can improve students' reasoning and life skills when they writing paper. At the end, students can answer questions (given in the form of test) based on their reasoning.

The findings of this research proves that daily living environment of students when used as a learning resource will be able to increase the activity and creativity students. The findings support several previous investigators including research Cross (1983) and Robenson (1977). Based on their research in lowa and California noted that the appreciation of the learning outcomes, creating an environment that supports the orientation of sociocultural factors, geography, and the existence conditions of the population, and can bring a positive attitude for students. To that end, model of learning that is done must be related to life skills for learners (Fatchan, Amirudin, and Soekamto, 2015). The provision of innovative information that surround the lives of students is necessary for an active and creative learning. Furthermore, learning groups based on field surveys to increase the motivation to learn, so that students are more enthusiastic about taking the subject matter (Fatchan and Amirudin, 2007). Learning groups will be easier for students to learn because there are times when the student is easier to learn than his own. There is also a student is easier to learn because of his own to teach or train in observing an object lesson in the field. By the time students can discuss with the group and to improve students' understanding of the material that is being observed. The impact would be able to improve student learning outcomes.

The results also reinforce the research findings Fatchan and Purwanto (2007). These findings indicate that learning field study directly in case of natural disaster-stricken areas for students Junior Midle School on "Social StudyGeography" subject matter can increase the activity and creativity and student learning outcomes. Additionally, causing criticality and courage of students when following Social-Geography lessons in the classroom. Further impacts, can improve learning outcomes Social-Geography students. That, in line with the concept that utilize learning resources that come from the environment around their homes, enables students to solve problems with the test well (Yager and Huang, 1994; Crawford, 2001; Johnson, 2002). To obtain maximum results necessary to learn Social-Geography teaching approaches based on the context of the environmental conditions surrounding the student (Fatchan et al, 2004).

\section{Conclusion}

Results of research conducted in the Junior Midle School in the area "Mataraman" East Java Province can be summarized as follows. First, the learning model "outdoor study" in the form of observations and interviews airy effect on the ability to communicate through writing in the form of paper. Second, the experimental class scores gain value is greater than the control class, so the learning outcomes social-geography experimental class is higher than the control class learning outcomes. In other words, that the learning outcomes of learning Social-geography using "outdoor study" is better than the conventional study conducted in the Junior Midle School in the area "Mataraman". There is a significant relationship between the results of learning Social-geography by learning "outdoor study" based on field observation and interviews. Learning "outdoor study" through observation and field interviews, not only can improve learning outcomes, but also can improve students' skills in writing papers in the field of Social-geography. Such learning is necessary implemented in Junior Midle School since been shown to improve the ability to write "papers" and student learning outcomes.

\section{Acknowledgement}

*The study was sponsored by Derektorat Research and Community Service. The Republic of Indonesia

\section{References}

Amirudin, Achmad; Ach. Fatchan; Budijanto. 2006. Development of Life Skills Education Model for "Anjal" by Using Chain of Response. Jakarta. Directorate General of Higher Education of the Republic of Indonesia and Research Institute of the State University of Malang.

Bruce, DM 1996. The Quiet In Science Education-Teaching Science The Way Students Learn. Journal of College Science Teaching, XXV (3): $169-171$.

College of Education. 2001. Training for Indonesia Educational Team In Contextual Teaching and Learning. Seattle, Washington, USA. University of Washington.

Crawford, Michael. 2001. Contextual Teaching and Learning: Strategy for Creative Constructivist Classroom. Connection (Online) 11 No. 6. Hyperlink. http://www.cord.org accessed 27-4-2002.

Dimyati and Mudjiono. 1994. Teaching and Learning. Jakarta. Project Development and Quality Improvement of Higher Education 
Personnel Director General.

Fatchan, Ach., et al. 2004. Evaluation of Basic Education Transformation in East Lombok. Malang. Research Institute of the State University of Malang and Plan International Indonesia.

Fatchan, Ach; Herdri Purwito; Marhadi, SK; Sukamto Hadi. 2005. Application of Project Based Learning for Students Department of Geography UM-Malang. Jakarta. Directorate General of Higher Education of the Republic of Indonesia and Research Institute of the State University of Malang.

Fatchan, Ach and Ach. Amirudin. 2007. Models of Learning Outdoor Study For Natural Disaster Prone Areas. Director General of Higher Education, DP2M, Jakarta - Lemlit UM-Malang, Malang

Fatchan, Ach; Achmad Amirudin, Sugeng Utaya. 2012. Comparative Study between the Indoor Outdoor Learning Study to Improve Learning Outcomes and Student Activities in the Field Junior Geography. Jakarta. Directorate General of Higher Education of the Republic of Indonesia and Research Institute of the State University of Malang.

Fatchan, Ach; Amirudin, Ach; and Soekamto, Hadi: 2015. Education Model of "Bandongan" for Farmers Society Agriculture Skill Training in the Background Socioculture "Pesantren" in East Java. Mediterranean Journal of Social Sciences. Rome-Italy. MCSER Publishing (Pp.515-523).

Geography Lecturer Team. 1995. Observation Field Study Learning Implementation and Use Media Audio Visual Aids. Malang. The research was financed by the OPF Program Malang Teachers' Training College.

Johnson, Elaine B. 2002. Contextual Teaching and Learning. Thousand Oaks, California: Corwin Press, Inc. A Soge Publications Company.

Nurhadi. 2002. Contextual Teaching and Learning Approach. Malang: Malang State University Press.

Rostana, E. Cecelia. 2002. Learning Contextual Teaching. Jakarta. Ministry of National Education Directorate General of Primary and Secondary Education Directorate junior high school.

Setjo, Susetyoadi. 2003. The Contextual Teaching and Learning: Education Oriented Life Skills Lessons hrough Biology. Papers presented in the workshop Piloting at the State University of Malang, 23 to 25 January 2003.

Staton, F. T, 1978, How to Teach Good Results, interpreting J F. Tahalele, Diponegoro and Bandung.

Team PPKI or Guidelines for Scientific Writing Team. 2010. Guidelines for Writing Paper. Malang. UM-Press.

The Ministry of National Education and Culture. 2000. Concept-Oriented Education Life Skills Through Broad-Based Education Approach. Jakarta. Ministry of Education.

The Ministry of National Education and Culture. 2002. Concept-Oriented Education Life Skills Through Broad-Based Education Approach. Book 1. Jakarta. Ministry of Education.

The Ministry of National Education and Culture. 2013. National Education Curriculum 2013. Jakarta. Office of the Ministry of Education and Culture of the Republic of Indonesia.

Yager, R. E. and Huang, Dar Sun. 1994. An Alternative Approach to College Science Education for nonscience Majors. Journal of College Science Teaching. November: 98-100.

The Ministry of National Education and Culture. 2000. Concept-Oriented Education Life Skills Through Broad-Based Education Approach. Jakarta. Ministry of Education.

The Ministry of National Education and Culture. 2002. Concept-Oriented Education Life Skills Through Broad-Based Education Approach. Book 1. Jakarta. Ministry of Education.

The Ministry of National Education and Culture. 2013. National Education Curriculum 2013. Jakarta. Office of the Ministry of Education and Culture of the Republic of Indonesia. 